\title{
PEMODELAN KADAR AIR PADA SIFAT FISIK STABILISASI TANAH GAMBUT
}

\author{
Mohammad Syaiful Pradana ${ }^{1}$, Awawin Mustana Rohmah ${ }^{2}$ \\ ${ }^{1,2}$ Universitas Islam Darul Ulum Lamongan
}

\begin{abstract}
Peat soil is an organic soil with very low carrying capacity and high compressibility. The condition is less profitable for civil engineers in building a civil foundation foundation. One method of peat soil improvement can be done with astabilization method that more environment-friendly and cheaper than other methods. Laboratory based peat stabilization studies to increase carrying capacity, reduce compression and improve peat soil physical properties have been conducted in Indonesia. The results of laboratory studies shown in the graph are still limited by time and content of the mixture. Therefore, further research is needed on the mathematical model toward the physical properties of peat soil stabilization. In this research will be formulated mathematical model of water content on the physical properties of peat soil stabilization. The model is derived from the fluid equation through porous media based on the principle of continum and controlvolume. The model is then resolved numerically by different method until MacCormack scheme with two steps are predictor step using forward difference and correctorstep using backward difference. The MacCormack scheme has the advantage of solving fluid flow equations and continuity. The model is then simulated and validated by comparing the simulation results with the real system. From the simulation results obtained the water content gradually decreased, the decrease is almost close to zero. In addition, it can be seen the difference in decrease in moisture content at each test point although in small quantities.
\end{abstract}

Keywords:Moisture Content, MacCormack, Peat Soil Stabilization.

\section{PENDAHULUAN}

Tanah gambut merupakan tanah organik dengan daya dukung sangat rendah dan kompresibilitas tinggi. Kondisi tersebut kurang menguntungkan bagi para civil engineer dalam membangun pondasi bangunan sipil diatasnya sehingga menyebabkan metode perbaikan tanah diterapkan untuk meningkatkan daya dukung dan meningkatkan kompressibilitas (Yulianto FE, 2016). Salah satu metode yang lebih berwawasan lingkungan dan murah dibandingkan metode lain yaitu metode stabilisasi. (Ma'ruf MA, 2016).

Metode stabilisasi dikembangkan dengan menggunakan bahan aditif seperti campuran kapur-abu terbang atau campuran kapur-abu sekam. Metode stabilisasi untuk tanah gambut tersebut dikembangkan oleh Yulianto, F.E (2012) menggunakan bahan campuran (admixture stabilizer) 70\% abu sekam padi (Rice Husk Ash) dan 30\% kapur (Lime) didapatkan gambut yang distabilkan dengan 10\% bahan campuran memberikan kenaikan kapasitas bantalan optimum dan penurunan kompresibilitas sehingga perbaikan menjadi lebih menonjol seiring bertambahnya waktu. Pengembangan metode stabilisasi lain dilakukan oleh Ma'ruf, M.A (2015) menyimpulkan bertambahnya umur stabilisasi maka reaksi bahan stabilisasi akan semakin lama pula. 
Penelitian stabilisasi tanah gambut berbasis laboratorium telah dilakukan di Indonesia. Hasil penelitian laboratorium yang ditampilkan dalam grafik masih dibatasi oleh waktu dan kadar bahan campuran.Oleh karena itu, dibutuhkan penelitian lebih lanjut mengenai model matematika ke arah sifat fisik stabilisasi tanah gambut, misalnya kadar air dan angka pori tanah gambut. Menurut Yulianto, F.E (2016) penurunan kadar air menyebabkan angka pori menjadi lebih kecil sehingga kuat geser meningkat dan kompressibilitas menurun.

Berdasarkan pada uraian diatas, pada penelitian ini diturunkan model matematika untuk kadar air pada sifat fisik stabilisasi tanah gambut. Model diturunkan dari persamaan fluida melalui media berpori berdasarkan prinsip kontinum dan volume kendali. Selanjutnya model diselesaikan secara numerik dengan metode beda hingga skema MacCormack dengan dua langkah yaitu langkah prediktor menggunakan beda maju dan langkah korektor menggunakan beda mundur. Skema MacCormack memiliki kelebihan untuk menyelesaikan persamaan aliran fluida dan kontinuitas. Selanjutnya model disimulasikan dan divalidasi dengan membandingkan hasil simulasi dengan sistem nyata.

\section{METODE PENELITIAN}

Parameter tanah gambut yang penting untuk menentukan sifat fisiknya adalah kadar air, angka pori, spesifik gravity, kadar organik, kadar abu, keasaman, kadar gas, rembesan, susut, batas konsistensi dan berat volume. Sifat fisik tersebut sangat dipengaruhi oleh material organik dan proses terbentuknya tanah gambut. Dalam penelitian ini, sifat fisik yang akan dirumuskan model matematisnya yaitu kadar air.

\section{A. Kadar Air}

Kadar air tanah gambut asli dalam kondisi jenuh dapat melebihi 600\%, namun secara umum variasi kadar airnya berkisar antara 500-1500\% seperti pengujian yang telah dilakukan oleh Yulianto, F.E (2016), tetapi kadar air tersebut akan berubah secara drastis apabila tercampur dengan bahan anorganik meskipun dalam kadar yang kecil.

B. Stabilisasi Tanah Gambut

Metode merupakan suatu cara perbaikan tanah dengan mencampurkan bahan kimia ke dalam tanah dengan tujuan agar dapat meningkatkan sifat fisik dan tekniknya. Metode stabilisasi banyak diaplikasikan pada tanah lempung yang memiliki daya dukung rendah atau tanah dengan nilai plastisitas tinggi (Expasive Soil). Material stabilisasi sering menggunakan kapur hidup $\mathrm{CaO}$ (Quick Lime), kapur padam $\mathrm{Ca}(\mathrm{OH}) 2$ (Calsium Hydroxide), abu sekam padi (Rice Husk Ash) dan abu terbang (Fly Ash). 
Model matematika dari percobaan stabilisasi tanah gambut di laboratorium diturunkan berdasarkan prinsip kontinum dan volume kendali menggunakan persamaan kekekalan massa dan persamaan kekekalan momentum pada media berpori berupa tanah gambut yang telah mendapatkan perlakuan seperti yang ditunjukkan Gambar 1.

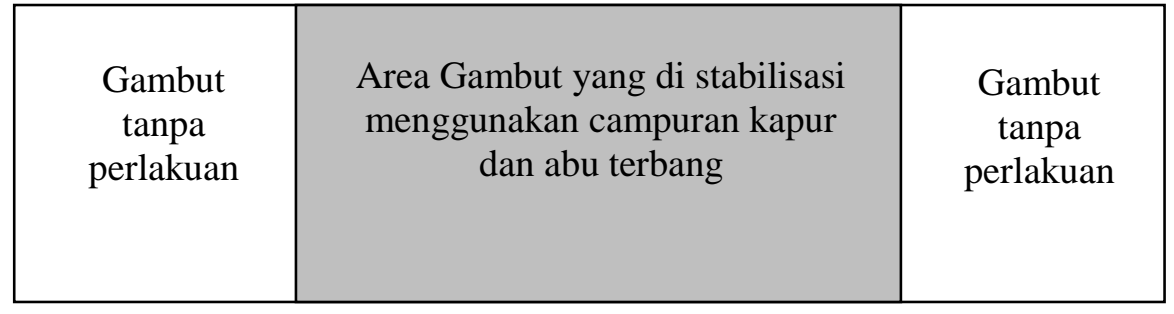

\section{Gambar 1. Model Stabilisasi Tanah Gambut}

Dari Gambar 1 sketsa model stabilisasi tanah gambut di laboratorium dihasilkan model matematika untuk mengetahui prilaku pertumbuhan kristal yang dibentuk dari gambut, kapur, abu terbang (fly ash) dan air. Terbentuknya kristal tersebut akibat dari reaksi kimia dari bahan campuran (kapur, fly ash dan air) (Pradana \& Widodo, 2014).

\section{Persamaan Konservasi Massa}

Prinsip fisik pertama yang diterapkan untuk konversi dari sistem ke deskripsi volume kontrol adalah prinsip konservasi massa yaitu massa sistem tetap konstan (Pritchard, 2011).

$$
\left.\frac{d M}{d t}\right)_{\text {sistem }}=0
$$

Dengan

$$
M_{\text {sistem }}=\int_{M(\text { sistem })} d m=\int_{V(\text { sistem })} \rho d V
$$

Formulasi sistem dan kontrol volume ditunjukkan pada (2) berikut

$$
\left.\frac{d N}{d t}\right)_{\text {sistem }}=\frac{\partial}{\partial t} \int_{C V} \eta \rho d V+\int_{C S} \eta \rho \vec{V} \cdot d \vec{A}
$$

Dengan

$$
N_{\text {sistem }}=\int_{M(\text { sistem })} \eta d m=\int_{V(\text { sistem })} \eta \rho d V
$$

Untuk mendapatkan formulasi kontrol volume dari konservasi massa, di misalkan $N=M$ dan $\eta=$. Selanjutnya dengan subtitusikannya ke (2) didapatkan 


$$
\left.\frac{d M}{d t}\right)_{\text {sistem }}=\frac{\partial}{\partial t} \int_{C V} \rho d V+\int_{C S} \rho \vec{V} \cdot d \vec{A}
$$

Selanjutnya dengan membandingkan (1) dan (3) didapatkan formulasi volume kontrol dari konservasi massa sebagai berikut.

$$
\frac{\partial}{\partial t} \int_{C V} \rho d V+\int_{C S} \rho \vec{V} \cdot d \vec{A}=0
$$

\section{Persamaan Darcy}

Persamaan yang menggambarkan mengenai aliran fluida pada media berpori pertama kali dikembangkan oleh Henry Darcy pada tahun 1856. Persamaan tersebut merupakan persamaan yang menunjukkan kecepatan aliran fluida dengan permeabilitas batuan, viskositas fluida serta gradient tekanan antar jarak tempuh aliran. Penyelidikan mengenai aliran fluida dalam media berpori berupa ground water juga dilakukan oleh Syahruddin, M.H (2014) menggunakan persamaan Darcy (5) berikut.

$$
u=\frac{q}{A}=k \frac{h_{1}-h_{2}}{L}=k \frac{\Delta h}{L}
$$

Dengan $u$ adalah kecepan aliran $(L / S), q$ adalah debit aliran $\left(L^{3} / S\right)$, A adalah luas penampang $\left(L^{2}\right), \Delta h$ adalah selisih permukaan fluida $\left(L^{2}\right), L$ adalah panjang media $(L)$ dan $k$ adalah konstanta konduktivitas. Nilai $k$ bergantung pada kondisi sifat padatan (solid matrix) dan sifat dari cairannya yaitu air.

\section{E. Metode Beda Hingga Skema MacCormack}

Dalam metode numerik terdapat beberapa metode salah satunya adalah Metode Beda Hingga (Finite Difference Method) dengan berbagai macam skema eksplisit dan implisit. Contoh skema eksplisit yaitu skema pengepingan MacCormack. Natakusumah (2007) menggunakan skema pengepingan MacCormack pada persamaan aliran 1 dimensi (Saint Venant Equation). Untuk lebih jelasnya dapat dilihat persamaanorde pertama (6) berikut.

$$
\frac{\partial u}{\partial t}+a \frac{\partial u}{\partial x}=0
$$

Tahap prediktor: pada tahap prediktor menggunakan skema maju, nilai sementara dari $u$ pada watu $n+1$ didenotasikan oleh $u_{i}^{\overline{n+1}}$ sehingga diperoleh (7) berikut.

$$
u_{i}^{\overline{n+1}}=u_{i}^{n}-a \frac{\Delta t}{\Delta x}\left(u_{i+1}^{n}-u_{i}^{n}\right)
$$


Tahap korektor: pada tahap korektor menggunakan skema mundur, nilai prediktor $i^{\overline{n+1}}$ dikoreksi berdasarkan (8) berikut.

$$
u_{i}^{n+1}=u_{i}^{n+\frac{1}{2}}-a \frac{\Delta t}{2 \Delta x}\left(u_{i}^{\overline{n+1}}-u_{i-1}^{\overline{n+1}}\right)
$$

Dengan step waktu yang digunakan dalam tahap korektor adalah $\frac{\Delta t}{2}$ dan mengganti bentuk $u_{i}^{n+\frac{1}{2}}$ dengan rata-rata sementara

$$
u_{i}^{n+\frac{1}{2}}=\frac{u_{i}^{n}+u_{i}^{\overline{n+1}}}{2}
$$

Sehingga menghasilkan tahap korektor sebagai berikut

$$
u_{i}^{n+1}=\frac{u_{i}^{n}+u_{i}^{\overline{n+1}}}{2}-a \frac{\Delta t}{2 \Delta x}\left(u_{i}^{\overline{n+1}}-u_{i-1}^{\overline{n+1}}\right)
$$

Selanjutnya untuk hasil korektor, persamaan (9) dapat ditulis menjadi :

$$
u_{i}^{n+1}=\frac{1}{2}\left[u_{i}^{n}+\left[u_{i}^{\overline{n+1}}-a \frac{\Delta t}{2 \Delta x}\left(u_{i}^{\overline{n+1}}-u_{i-1}^{\overline{n+1}}\right)\right]\right]
$$

Penggunaan metode beda hingga skema MacCormack memiliki kelebihan untuk menyelesaikan persamaan aliran fluida, berguna dalam memecahkan persamaan kontinuitas dan persamaan momentum dua dimensi yang merupakan persamaan diferensial parsial non-linier dalam ruang dan waktu (Natakusumah, 2007).

\section{HASIL DAN PEMBAHASAN}

Pada stabilisasi tanah gambut menggunakan bahan campuran kapur, fly ash dan air. Pencampuran tersebut menyebabkan terjadinya reaksi kimia yang membuat meningkat kepadatannya sehingga daya dukung tanah gambut meningkat. Berikut persamaan reaksi kimia (11) yang dihasilkan.

$$
\begin{gathered}
\mathrm{CaCO}_{3}+\mathrm{H}_{2} \mathrm{O} \rightarrow \mathrm{Ca}(\mathrm{OH})_{2}+\mathrm{CO}_{2} \\
\mathrm{SiO}_{2}+\mathrm{H}_{2} \mathrm{O} \rightarrow \mathrm{H}_{2} \mathrm{SiO}_{3} \\
\mathrm{Ca}(\mathrm{OH})_{2}+2 \mathrm{H}_{2} \mathrm{SiO}_{3} \rightarrow \mathrm{Ca}\left(\mathrm{HSiO}_{3}\right)+2 \mathrm{H}_{2} \mathrm{O}
\end{gathered}
$$

Dengan $\mathrm{Ca}(\mathrm{OH})_{2}$ adalah kalsium hidroksida, $\mathrm{CO}_{2}$ adalah karbon dioksida, $\mathrm{H}_{2} \mathrm{SiO}_{3}$ adalah asam silicid. 
Tabel 1. Reaksi Stoikiometri

\begin{tabular}{ccc}
\hline Senyawa & Koefisien & Molar \\
\hline $\mathrm{Ca}(\mathrm{OH})_{2}$ & 1 & 74,09 \\
\hline $\mathrm{H}_{2} \mathrm{SiO}_{3}$ & 2 & 78,10 \\
\hline $\mathrm{Ca}\left(\mathrm{HSiO}_{3}\right)_{2}$ & 1 & 194,26 \\
\hline $\mathrm{H}_{2} \mathrm{O}$ & 2 & 18,02 \\
\hline
\end{tabular}

$$
\text { dengan } k=\frac{\left[\mathrm{Ca}\left(\mathrm{HSiO}_{3}\right)\right]\left[\mathrm{H}_{2} \mathrm{O}\right]}{\left[\mathrm{Ca}(\mathrm{OH})_{2}\right]\left[\mathrm{H}_{2} \mathrm{SiO}_{3}\right]}=\frac{3500,57}{5786,43}=0,60
$$

Laju reaksi dipertimbangkan karena pentingnya kemampuan untuk meramalkan kecepatan campuran reaksi mendekati kesetimbangan. Laju reaksi dapat ditentukan dengan cara mengikuti perubahan sifat selama terjadinya reaksi. Dengan menganalisis campuran reaksi dalam selang waktu tertentu, maka konsentrasi reaktan dan produk reaksi dapat dihitung. Persamaan laju reaksi ditentukan berdasarkan konsentrasi awal setiap zat, dipangkatkan orde reaksinya. Orde reaksi berpengaruh pada laju reaksi jika

$$
v=-\frac{d[A]}{d t}
$$

Persamaan laju reaksinya (12) adalah

$$
v=k[A]^{x}[B]^{y}
$$

$x$ dan $y$ adalah orde reaksinya, untuk setiap konsentrasi yang sama pada produk reaksi dinyatakan :

Untuk orde reaksi orde ke nol :

$$
\begin{gathered}
A \rightarrow \text { produk reaksi } \\
\quad v=k[A]^{0}=k
\end{gathered}
$$

Untuk orde reaksi orde satu :

$$
\begin{gathered}
A \rightarrow \text { produk reaksi } \\
\qquad v=k[A]
\end{gathered}
$$

Untuk orde reaksi orde dua :

$$
\begin{gathered}
2 A \rightarrow \text { produk reaksi } \\
v=k[A]^{2}
\end{gathered}
$$

Karena laju reaksi berbanding lurus dengan konsentrasi-konsentrasi zat pereaksi, maka dapat menggunakan laju terintegrasi pada (13) berikut. 


$$
\begin{aligned}
& -\frac{d[A]}{d t}=k[A]_{t}^{n} \\
& -\int \frac{d[A]}{[A]_{t}^{2}}=\int k d t
\end{aligned}
$$

Dengan $n=$ orde reaksi, $k=$ konstanta laju reaksi, $t=$ waktu. Untuk orde reaksi orde dua yang telah diintegralkan diperoleh

$$
\frac{1}{[A]_{t}}=k t+c
$$

Berthoud (1912) dan Valeton (1924) menggambarkan model perubahan massa dengan pertumbuhan dua tahap, yaitu proses difusi, dimana molekul solute berpindah dari bulk fase liquid ke permukaan solid. Daya dorong terjadinya kedua tahap ini adalah perbedaan konsentrasi yang dapat ditunjukkan oleh (15) berikut:

$$
\frac{d m}{d t}=k A\left(c-c_{e q}\right)
$$

Persamaan (15) dapat dibangun persamaan massa padatan dengan $m=\rho_{s} \forall$. Karena gambut merupakan media berpori, besarnya nilai porositas berpengaruh terhadap besarnya nilai volume padatan dalam gambut tersebut, volume padatan tersebut dapat dituliskan sebagai $\forall=(1-\phi)$, konstanta laju reaksi $k$ dan Diasumsikan bahwa $\phi$ suatu konstan pada waktu $t$ diperoleh

$$
\frac{d \rho_{s}}{d t}=\frac{k A\left(c-c_{e q}\right)}{(1-\phi)}
$$

Persamaan (16) diketahui bahwa perubahan massa padatan gambut dipengaruhi oleh perubahan laju pertumbuhan, perubahan konsentrasi serta perubahan porositas dari gambut. Perubahan tersebut dapat didapatkan dengan menggunakan Persamaan kekekalan massa dan momentum berdasarkan volume kendali melalui media berpori.

Menurut prinsip kontinum hukum kekekalan massa disebutkan bahwa aliran massa yang masuk dikurangi dengan aliran massa yang keluar sama dengan jumlah massa yang disimpan. 


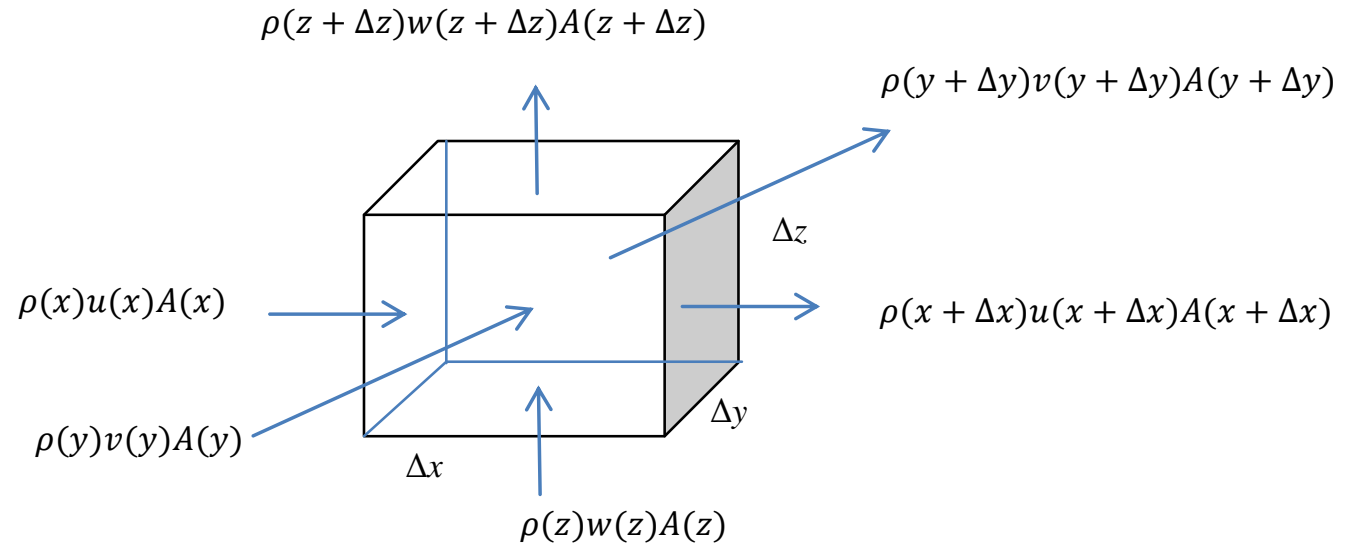

Gambar 2. Volume Kendali Aliran Massa

Jika volume kendali pada gambar 2 diperbesar dan digambarkan arah aliran massanya dari permukaan yang berjarak $\Delta x$ dari pusat elemen dinyatakan berturut-turut sebagai $\rho(x) u(x) A(x)$ dan $\rho(x+\Delta x) u(x+\Delta x) A(x+\Delta x)$, maka dari hukum kekekalan massa diatasdapat dijabarkan menjadi

$$
\begin{gathered}
\left((\rho(x) u(x) A(x))_{e}-(\rho(x+\Delta x) u(x+\Delta x) A(x+\Delta x))_{w}\right) \Delta t+ \\
\left((\rho(y) v(y) A(y))_{n}-(\rho(y+\Delta y) v(y+\Delta y) A(y+\Delta y))_{s}\right) \Delta t+ \\
\left((\rho(z) w(z) A(z))_{t}-(\rho(z+\Delta z) w(z+\Delta z) A(z+\Delta z))_{b}\right) \Delta t= \\
m(t+\Delta t)-m(t) \\
A(x)_{e}=A(x+\Delta x)_{w}=\Delta y \Delta z, \\
\text { Dengan } A(y)_{n}=A(y+\Delta y)_{s}=\Delta x \Delta z, \\
A(z)_{t}=A(z+\Delta z)_{b}=\Delta x \Delta y
\end{gathered}
$$

Selanjutnya membagi (17) dengan $\Delta t$, dan mengambil limit $\Delta t \rightarrow 0$ pada ruas kanan, maka diperoleh

$$
\begin{aligned}
& (\rho u(x)-\rho u(x+\Delta x)) \Delta y \Delta z+(\rho v(y)-\rho v(y+\Delta y)) \Delta x \Delta z+ \\
& (\rho w(z)-\rho w(z+\Delta z)) \Delta x \Delta y=\lim _{\Delta t \rightarrow 0} \frac{m(t+\Delta t)-m(t)}{\Delta t}=\frac{\partial m}{\partial t}
\end{aligned}
$$

Karena $m=\rho V_{p}$, jika $V_{p}=\phi V$ adalah volume pori maka $m=\rho \phi \Delta x \Delta y \Delta z$. Selanjutnya membagi (18) dengan $\Delta x \Delta y \Delta z$ diperoleh

$$
\begin{aligned}
& \frac{(\rho u(x)-\rho u(x+\Delta x))}{\Delta x}+\frac{(\rho v(y)-\rho v(y+\Delta y))}{\Delta y}+ \\
& \frac{(\rho w(z)-\rho w(z+\Delta z))}{\Delta z}=\frac{\partial \rho \phi}{\partial t}
\end{aligned}
$$

Ambil limit $\Delta x \rightarrow 0, \Delta y \rightarrow 0, \Delta z \rightarrow 0$ pada ruas kiri (19), maka diperoleh 


$$
\frac{\partial}{\partial x}(\rho u)+\frac{\partial}{\partial y}(\rho v)+\frac{\partial}{\partial z}(\rho w)=-\frac{\partial}{\partial t}(\rho \phi)
$$

Dengan $\rho$ adalah massa jenis fluida, $u$ adalah laju aliran fluida arah longitudinal, $v$ adalah laju aliran fluida arah lateral, $w$ adalah laju aliran fluida arah vertikal, dan $\phi$ adalah porositas. Dengan menggunakan turunan parsial pada (20) dan karena dilihat dalam arah longitudinal maka diperoleh

$$
u \frac{\partial \rho}{\partial x}+\rho \frac{\partial u}{\partial y}=-\left(\phi \frac{\partial \rho}{\partial t}+\rho \frac{\partial \phi}{\partial t}\right)
$$

Perubahan porositas terhadap waktu didapatkan dengan menggunakan hukum kekekalan massa yaitu perubahan rata-rata massa dalam kontrol volume ditambah dengan arus massa yang melalui kontrol volume sama dengan banyak massa yang diciptakan dari sumbernya atau hilang. Menurut teorema pengangkutan Reynold

Rate of change of mass in cell + net outward mass flux $=0$

$$
\frac{d}{d t}(\rho \forall)+\sum_{\text {faces }} \rho \mathrm{u} . A=0
$$

Dengan menggunakan aliran massa, maka (22) dapat dijabarkan menjadi

$$
\begin{aligned}
& \frac{\partial}{\partial t}(\rho \phi \forall)\left(\rho u \phi+\frac{\partial \rho u \phi}{\partial x} \Delta x-\rho u \phi\right) \Delta y \Delta z+\frac{\partial}{\partial t}(\rho \phi \forall)\left(\rho v \phi+\frac{\partial \rho v \phi}{\partial y} \Delta y-\right. \\
& \Delta x \Delta z+\frac{\partial}{\partial t}(\rho \phi \forall)\left(\rho w \phi+\frac{\partial \rho w \phi}{\partial z} \Delta z-\rho w \phi\right) \Delta x \Delta y=0
\end{aligned}
$$

Persamaan (23) dibagi dengan $\Delta x \Delta y \Delta z$ dan diasumsikan aliran incompressible maka $\rho$ konstan dan ditambahkan dengan komponen transfer massa dari hasil reaksi kimia sehingga diperoleh

$$
\rho\left(\frac{\partial \phi}{\partial t}+\frac{\partial u \phi}{\partial x}+\frac{\partial v \phi}{\partial y}+\frac{\partial w \phi}{\partial z}\right)+\Gamma=0
$$

Dengan $\Gamma=k A\left(c-c_{e q}\right)$. Selanjutnya menggunakan turunan parsial dan diambil dalam arah longitudinal diperoleh

$$
\frac{\partial \phi}{\partial t}=-\left(u \frac{\partial \phi}{\partial x}\right)-\frac{k A\left(c-c_{e q}\right)}{\rho}
$$

Setelah diperoleh model pada (14), (16), (21) dan (25) dilanjutkan dengan membentuk persamaan menjadi persamaan non dimensional untuk memudahkan dalam simulasi tanpa bergantung pada satuan dan dimensi. Selanjutnya penyelesaian secara numerik 
menggunakan metode beda hingga skema MacCormack. Dalam hal ini diberikan hasil untuk tahap prediktor dan korektor dari (21) sebagai berikut.

\section{Tahap prediktor}

$$
\phi_{i}^{n} \frac{\rho_{i}^{n+1}-\rho_{i}^{n}}{\Delta t}+\rho_{i}^{n} \frac{\phi_{i}^{n+1}-\phi_{i}^{n}}{\Delta t}=-u_{i}^{n}\left(\frac{\rho_{i+1}^{n}-\rho_{i}^{n}}{\Delta x}\right)-\rho_{i}^{n}\left(\frac{u_{i+1}^{n}-u_{i}^{n}}{\Delta x}\right)
$$

Tahap korektor

$$
\rho_{i}^{n+1}=\frac{1}{2}\left[\rho_{i}^{n}+\left[\rho_{i}^{\overline{n+1}}+\frac{\Delta t}{\phi_{i}^{n}}\left[\rho_{i}^{\overline{n+1}}\left(\frac{2 \phi_{i}^{n+1}-\phi_{i}^{n}+\phi_{i}^{\overline{n+1}}}{\Delta t}\right)-u_{i}^{n}\left(\frac{\rho_{i}^{\overline{n+1}}-\rho_{i-1}^{\overline{n+1}}}{\Delta x}\right)-\rho_{i}^{\overline{n+1}}\left(\frac{u_{i}^{n}-l}{\Delta x}\right.\right.\right.\right.
$$

Berikut ini merupakan hasil simulasi numerik menggunakan metode beda hingga skema MacCormack untuk laju reaksi kimia, massa padatan gambut dan kadar air gambut yang ditunjukkan pada masing-masing gambar 3, gambar 4 dan gambar 5 berikut.

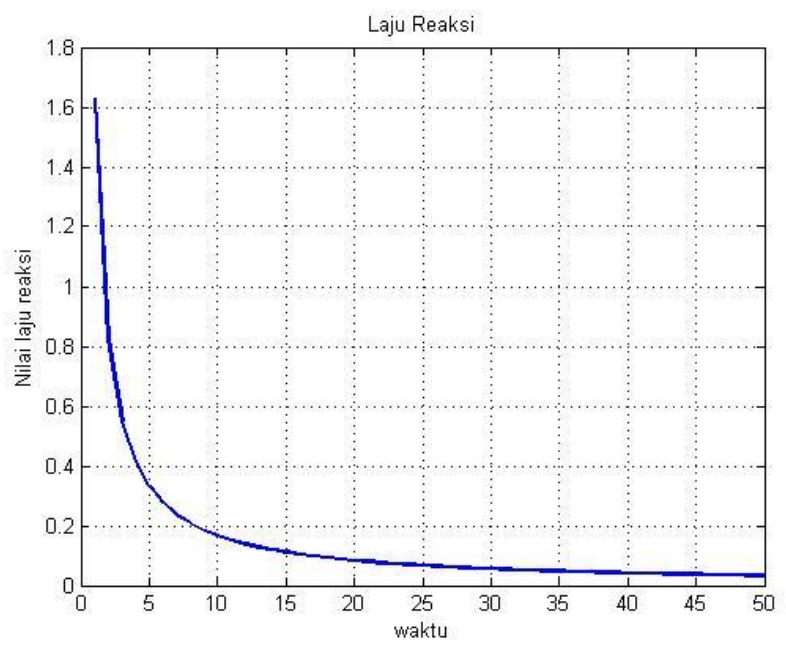

\section{Gambar 3. Laju Reaksi}

Pada plot gambar 3 diketahui bahwa konsentrasi laju reaksi pada reaktan mengalami penurunan setiap waktu. Penurunan tersebut berlangsung hingga mendekati nol yang artinya pada saat waktu tertentu proses reaksi kimia akan berhenti. 


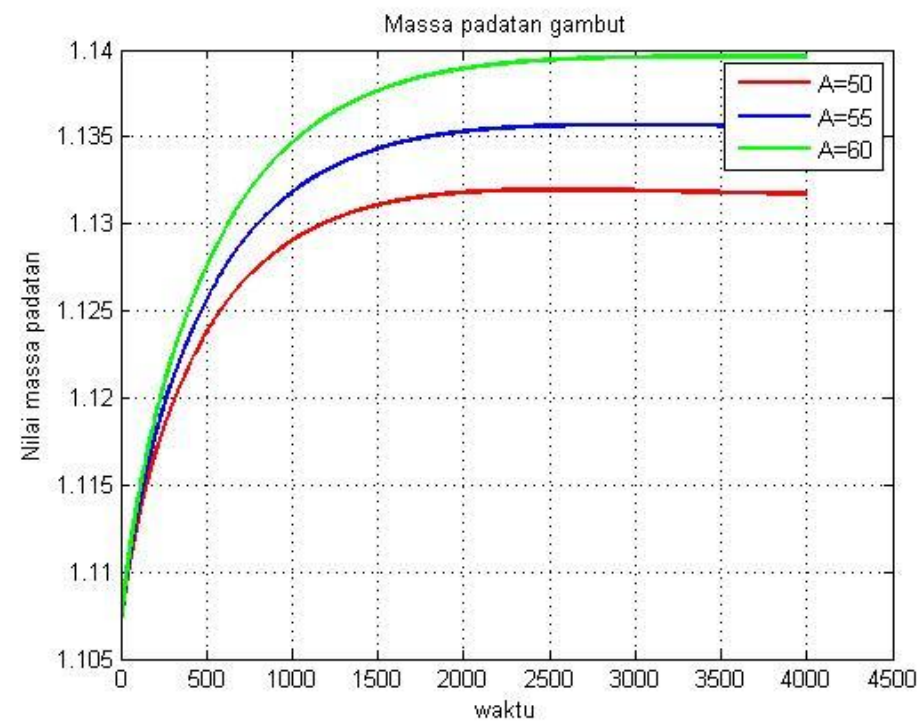

\section{Gambar 4. Massa Padatan Gambut}

Selanjutnya pada plot gambar 4 diketahui bahwa terjadi peningkatan massa padatan gambut akibat dari proses rekasi kimia. Selain itu, diketahui bahwa luas penampang yang lebih besar pada media gambut memiliki nilai massa padatan lebih tinggi dibandingkan dengan luas penampang lebih kecil.

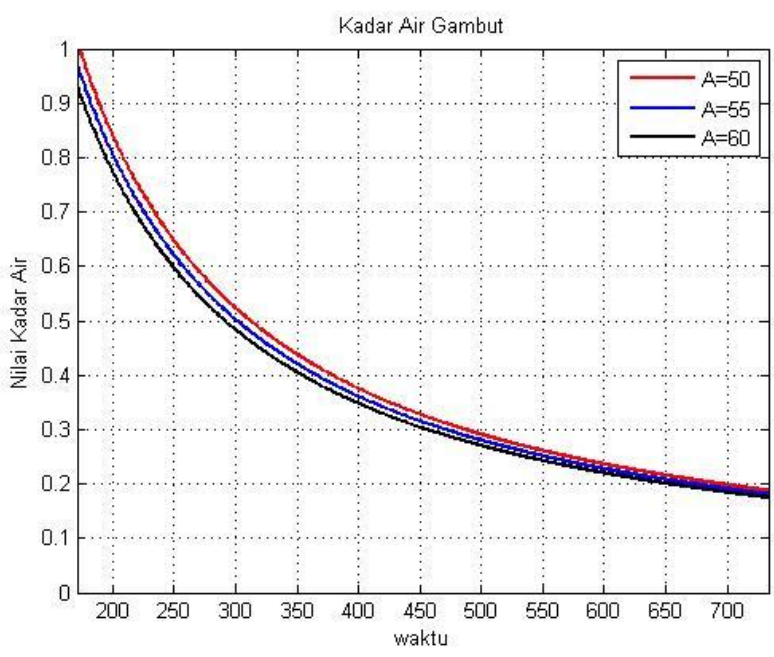

Gambar 5. Kadar Air Gambut

Pada plot gambar 5 diketahui bahwa selama proses reaksi terjadi penurunan kadar air pada gambut. Hal ini terjadi akibat air yang diserap oleh gambut selama proses stabilisasi berlangsung.

\section{SIMPULAN DAN SARAN}

Berdasarkan hasil dan pembahasan disimpulkan bahwa konsentrasi laju reaksi pada reaktan mengalami penurunan setiap waktu, adanya peningkatan massa padatan 
gambut stabilisasi akibat dari proses reaksi kimia, dan penurunan kadar air pada gambut stabilisasi. Hal ini terjadi akibat air yang diserap oleh gambut selama proses stabilisasi berlangsung.

Saran untuk penelitian lebih lanjut dapat menggunakan sifat fisik gambut yang lain misalnya angka pori gambut dan diselesaikan dengan menggunakan metode lain untuk menyelesaikan permasalahan yang lebih kompleks lagi.

\section{DAFTAR PUSTAKA}

Ma'ruf, MA., Syauqiah, I, 2015, Efek Waktu Pemeraman Terhadap Karakteristik Sifat Fisiktanah Gambut Dengan Bahan Stabilisasi Serbuk Kayu, Prosiding Seminar Nasional Teknik Sipil Unlam, ISBN 978-602-648-300-3, pg 333-344.

Ma'ruf, MA., Yulianto, FE, 2016, Tanah Gambut Berserat : Solusi dan Permasalahannya Dalam Pembangunan Infrastruktur Yang Berwawasan Lingkungan, Prosiding Seminar Nasional Geoteknik, ISBN 978-602-6483-02-7, pg 279-292.

Natakusumah, DK, 2007, Pemodelan Hubungan Hujan dan Aliran Permukaan Pada Suatu DAS dengan Metoda Beda Hingga, Prosiding ITB Sains dan Teknologi, Vo.39 No.1\&2, pg 97-123.

Pritchard, PJ., Leylegian, JC, 2011, Introduction to Fluid Mechanic, USA, John wiley \& Sons.Inc.

Pradana, M. S., \& Widodo, B. (2014). Model Pertumbuhan Kristal Pada Gambut (XVII). Surabaya: Konfrensi Nasional Matematika XVII. Retrieved from http://knm17.its.ac.id/

Syahruddin, MH, 2014, Persamaan Aliran Air Dalam Media Berpori Sebagai Aliran Air Tanah (GroundWater), Simposium Fisika Nasional SFN XXVII, ISSN 14114771.

Yulianto, FE, Mochtar, NE, 2012, Behavior of Fibrous Peat Soil Stabilized With Rice Husk Ash (RHA) and Lime, Proceeding of $8^{\text {th }}$ International Symposium on Lowland Technology, ISBN 978-602-95227-1-6, pg 106-110.

Yulianto, FE., Mochtar, NE, 2016, The Effect Of Water Pore Condition To Shear Strength And Compression Behavior Of Stabilized Fibrous Peat Mixing Lime Caco3 And Rice Husk Ash, International Journal of Applied Engineering Research, ISSN 0973-4562, Vol.11 No.15, pg 8578-8582. 